\title{
MOVEMENT AND MICRODISTRIBUTION OF SIDA CRYSTALLINA AND OTHER LITTORAL MICROCRUSTACEA ${ }^{1}$
}

\author{
G. WINFIELD FAIRCHILD ${ }^{2}$ \\ Division of Biological Sciences, University of Michigan, Ann Arbor, Michigan 48109 USA
}

\begin{abstract}
Littoral invertebrates of Cochran Lake, Michigan were either highly "plant-associated," and found infrequently away from aquatic macrophytes, or "free-swimming" among the plants.

Plant-associated taxa were distributed according to available surface area. Numbers of periphyton and detritus feeders, chiefly chydorid Cladocera and chironomid midge larvae, were highly correlated with diatom density, whereas filter-feeding Cladocera attached to the plants (Sida, Simocephalus) were not. Cyclopoid copepods characteristic of the littoral during the day (Macrocyclops, Eucyclops, and Microcyclops) were also found primarily on aquatic plant surfaces. Abundances of the chydorid Cladocera increased slightly at night, while other taxa showed little diurnal variation.

Free-swimming species in the littoral (Bosmina, Ceriodaphnia) sometimes formed large patches covering many square metres. Larger species (Mesocyclops, Diaptomus, Epischura) greatly increased the numbers and diversity of this community at night.

Sida crystallina, a filter feeder typically attached to plant surfaces, nonetheless swims frequently and well if disturbed. Juveniles moved between substrates more frequently than adults, and were found nearer the surface. Sites for reattachment were located visually. Frequent and often extensive episodes of swimming, especially by juveniles, provided a plausible explanation for the high concentrations of Sida observed on isolated plants, particularly those on the margins of stands of aquatic vegetation.
\end{abstract}

Key words: aquatic macrophytes; Chydoridae; Cladocera; invertebrates; littoral; microdistribution; patchiness; periphyton.

\section{INTRODUCTION}

Studies of the microdistribution and abundance of littoral microcrustacea have generally been few compared to similar work done with the plankton. Notable exceptions have been the work of Goulden (1971) and of Whiteside and co-workers $(1974,1978)$ on the ecology of benthic chydorids, of Rosine (1955), Smyly (1958), Quade (1969), and others on plant-associated communities, and of Johnson (1973), Keen (1973), Daggett and Davis (1974), and Phoenix (1976) on the population dynamics of littoral species. A major obstacle to quantitative studies has been sampling, and publications on sampling methods (Gerking 1957, Pennak 1962, Gillespie and Brown 1966, Whiteside and Williams 1975, and Minto 1977) have addressed this problem. As difficulties in sampling are solved, studies of the littoral should contribute increasingly to both population and community ecology.

This paper summarizes six experiments on the behavior and microdistribution of Sida crystallina. The microdistribution of other invertebrates, especially the chydorid Cladocera Alona costata and Acroperus harpae, total chydorids and total chironomid larvae, are also presented and compared with those of Sida.

Thomas (1963) has reviewed the morphology and behavior of three forms of Sida crystallina, two of

\footnotetext{
1 Manuscript received 6 May 1980; revised 27 October 1980; accepted 1 December 1980.

2 Present address: Biology Department, Central Michigan University, Mount Pleasant, Michigan 48859 USA.
}

which are limnetic and rarely observed. The common form considered here attaches to aquatic macrophytes by means of a cervical gland, and thus filter feeds from a fixed position. Specific questions relating to that adaptation are treated by the six experiments:

1) Both vertical and horizontal movement is known to be an important feature of the ecology of limnetic Cladocera. How frequent is movement between plants by a plant-associated filter feeder?

2) How are new plants located when movement between plants occurs?

3) Sida cannot benefit from, and may be inhibited by, large amounts of periphyton and large numbers of invertebrate grazers feeding upon periphyton. In a heterogeneous environment of young and old plants, is Sida more abundant on "cleaner" surfaces?

4) Are population densities of Sida strongly limited by surface area for attachment, and how does movement of individuals between plants affect population densities on isolated vs. densely clustered plants?

5) Is attachment strictly a means of avoiding visual predation?

6) Free-swimming Cladocera of the littoral are often concentrated in "patches" covering many square metres of lake surface, whereas periphyton grazers apparently are not. Does a "pseudo-plankter" (Gliwicz and Rybak 1976) like Sida conform more to the distributional patterns of free-swimming plankton feeders or to those of plant-associated periph- 
TABLE 1. Frequency of movement of Sida as a function of body size (Experiment $A$ ).

\begin{tabular}{ccc}
\hline $\begin{array}{c}\text { Size class } \\
(\mathrm{mm})\end{array}$ & $\begin{array}{c}\text { \% individuals } \\
\text { still attached } \\
\text { at } 45 \mathrm{~min}\end{array}$ & $\begin{array}{c}\text { Mean time } \\
\text { until movement } \\
\text { in minutes: } \\
\bar{x}(\mathrm{SE})\end{array}$ \\
\hline$<1.0$ & $19.6(13 / 66)$ & $13.8(1.6)$ \\
$1.0-1.4$ & $23.6(13 / 55)$ & $20.2(2.1)$ \\
$1.4-1.8$ & $33.9(19 / 56)$ & $19.8(2.1)$ \\
$>1.8$ & $71.1(32 / 45)$ & $16.5(3.8)$ \\
\hline
\end{tabular}

yton grazers? If patches occur, where in the littoral do they occur?

Two experiments of the degree of movement by Sida crystallina between plants, and the means by which the animal locates plants for reattachment, were conducted at the University of Michigan Biological Station at Pellston, Michigan, USA. Four field experiments were also performed in Cochran Lake, Cheboygan County, Michigan, $\approx 27 \mathrm{~km}$ south of the Biological Station. Surface area of the lake is 11.0 ha; maximum depth is about $3.5 \mathrm{~m}$. Aquatic macrophytes dominate the shallow margins during the summer months. Monospecific stands of Nymphaea odorata form habitat islands which ring the southern and western ends of the lake; Scirpus spp., Carex spp., and other emergents are also abundant at the eastern end.

\section{Experiment A: Movement between Plants}

\section{Methods}

Smaller individuals of Sida were frequently observed in laboratory cultures to swim freely in the water. This age-specific tendency to swim between substrates was subsequently quantified photographically. A Plexiglas chamber of dimensions $8 \times 4 \times 4$ $\mathrm{cm}$ was constructed, with an incised grid of dimensions $2 \times 4 \mathrm{~mm}$ on the inner wall of one of the sides. The chamber was filled with water from Cochran Lake. The water was filtered through a 70- $\mu \mathrm{m}$ mesh screen, and allowed to warm to room temperature. Sida, also from Cochran Lake, readily attached to the Plexiglas when introduced into the chamber. Photographs were then taken of the gridded side of the chamber at 3-min intervals for a total of 45 min using a Vivitar 55-mm macro lens. Lighting was provided by a 100-W incandescent bulb placed above the chamber, with an intervening water bath $6 \mathrm{~cm}$ deep used as a heat filter. Temperatures were kept at $23 \pm 2^{\circ} \mathrm{C}$ in each of the eight trials conducted. A black Plexiglas sheet placed in the water behind the gridded side of the chamber served to highlight the organisms with sufficient clarity that all individuals could be assigned to one of four size categories by comparing body length to the known grid dimensions in the photographs. Densities varied from 1.4 to 2.2 individuals/ $\mathrm{cm}^{2}$ on the gridded surface, with nearest neighbor dis- tances varying from 0 to $>10 \mathrm{~mm}$. "Time until movement" was computed from the start of the experiment (the time of the original photograph) to the time of the first photograph in which a given individual had vacated its original position. Data for subsequent movements by reattached individuals were not compiled. The percentages of individuals of each size category which had not moved during the 45 -min trials were also calculated; values for each of the size classes and of large $(>1.8 \mathrm{~mm})$ vs. smaller $(<1.8 \mathrm{~mm})$ individuals were compared using the binomial test.

\section{Results}

Probabilities of movement for individuals of the four size classes are presented in Table 1. Large individuals $(>1.8 \mathrm{~mm})$ had a significantly greater tendency $(P<$ $.001)$ to remain in a fixed position than did smaller $(<1.8 \mathrm{~mm})$ individuals. Times until first movement of those individuals which did move during the $45 \mathrm{~min}$ were quite variable; mean values were found to be generally similar for all size classes.

Movement by individuals during the experiment was initiated in part by physical contact with other individuals, but frequently occurred without any obvious disturbance. Doubtless the density of conspecifics and of other plant-associated species may modify the actual rates of movement. Algal food density, water chemistry and substrate type may also influence movement probabilities. Clearly, however, smaller individuals are likely to respond to such environmental effects by moving more frequently than do large individuals.

\section{Experiment B: The Mechanism of Searching for New Plants}

\section{Methods}

A second experiment was designed to test the ability of individuals swimming between plants to detect substrates for reattachment. A clear, round Plexiglas chamber $58.5 \mathrm{~cm}$ in diameter and $8 \mathrm{~cm}$ in height was constructed. Alternate clear and opaque Plexiglas blocks of $0.5 \mathrm{~cm}$ thickness and $2.5 \mathrm{~cm}$ width were positioned $19 \mathrm{~cm}$ from the center of the chamber and spaced $2.5 \mathrm{~cm}$ apart (Fig. 1).

Three series of observations were made. Two of them were conducted outdoors in the same location but at different times of the day; the third experiment was conducted indoors at night, and made use of a 300 -W flood lamp positioned $\approx 1 / 2 \mathrm{~m}$ from the chamber. The lamp provided $\approx 300 \mu \mathrm{E} \cdot \mathrm{m}^{-2} \cdot \mathrm{s}^{-1}$ of highly directional lateral light reaching the center of the chamber. In addition, an overhead bank of fluorescent lights supplied $\approx 20 \mu \mathrm{E} \cdot \mathrm{m}^{-2} \cdot \mathrm{s}^{-1}$ of light to the chamber, and was sufficient to allow observation of individual Sida.

Individuals were released from an eyedropper, one at a time, at the center of the chamber, and were allowed to swim until contacting a block, passing be- 

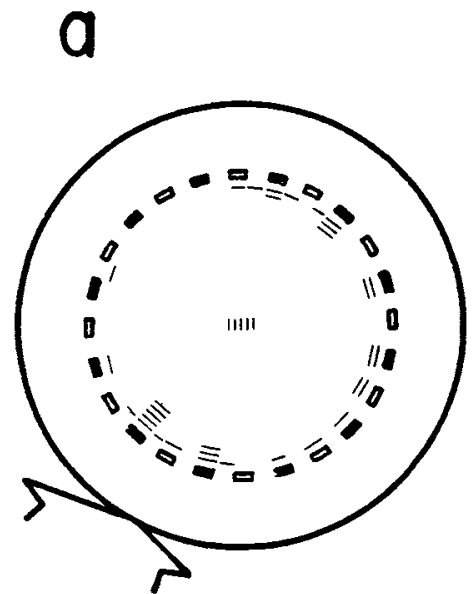

b

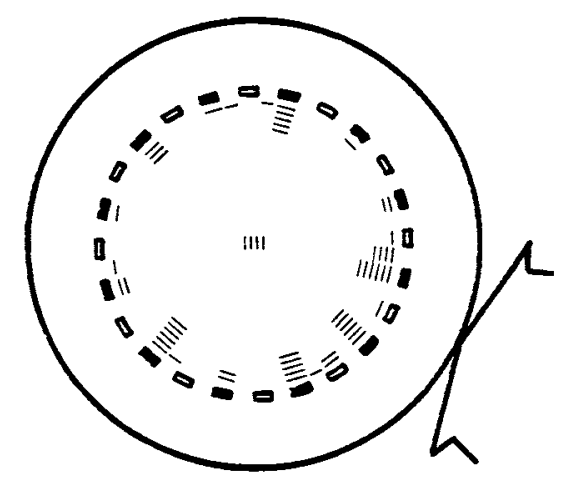

C

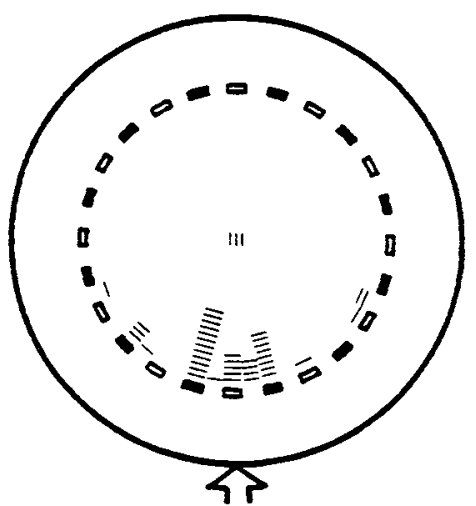

Fig. 1. Reattachment behavior of Sida (Experiment B). Single lines denote locations where individuals contacted a clear or opaque block, passed between two blocks, or attached to the bottom of the chamber (lines placed at the center of each diagram). The thickness of the arrows indicates the degree of change in direction of light during each experiment. a: midafternoon 1 May, sunny $(n=37)$; b: late morning 4 May, overcast $(n=57)$; : at night using artificial light $(n=42)$.

tween two blocks, or attaching to the bottom of the chamber. Only ovigerous females were used in the experiment, as smaller individuals often displayed little tendency to attach.

\section{Results}

Initial swimming behavior following entry into the center of the chamber was usually rapid, and was replaced soon after by the slow "hopping" motion characteristic of most free-swimming Cladocera. Movements of the thoracic appendages, presumed to be filter feeding, in fact occurred during this slower swimming. As the individual approached an available surface, it again swam rapidly and reattached. Such behavior suggested that individuals sense the presence of substrates for reattachment, often from distances of $10 \mathrm{~cm}$ or more. Results of the three series of trials (Fig. 1a-c) demonstrated that individuals are indeed capable of locating plants. The following three hypotheses were specifically tested:

1. If individuals cannot in any way sense the Plexiglas blocks prior to contact, then the number of individuals contacting the 24 blocks should equal the number passing between blocks, as both blocks and spaces were $2.5 \mathrm{~cm}$ wide. The binomial test was used to evaluate the three experiments performed. All showed significantly higher $(P<.01)$ contact with the blocks than would be expected from random swimming behavior.

2. If individuals do not locate blocks visually, then the frequency of contacting opaque and clear blocks should be equivalent. This, too, was rejected at $P<.01$ for all three experiments. Vision (discrimination between light and dark objects) is quite obviously involved in reattachment.

3. If sight alone is important, then the frequency of contacting the 12 clear blocks should be approximately one-half the frequency of passing through the 24 spaces between blocks. This hypothesis was not rejected in any of the experiments. There was no evidence that Sida uses means other than visual perception to locate substrates for reattachment.

One implication of the results is certainly an increased probability for long-range swimming at night. Diurnal effects upon the degree of attachment to plants were further examined in Experiment 3.

\section{EXPERIMENT 1: EFFECTS OF DiATOM DENSITY AND DEPTH}

\section{Methods}

A stand of Scirpus validus, located at the eastern end of Cochran Lake, was used for the experiment. An area was chosen $1 \times 2 \mathrm{~m}$ in size, averaging $0.8 \mathrm{~m}$ in depth, and containing both brown stems from the previous year and recently emerged green stems. Samples of the stems were collected by a person standing in the water next to the quadrat, and transferred to a second person in an adjacent rowboat for preservation and labelling. Thirty-two samples were taken on 20 August 1978, 16 from young green stems and 16 from brown stems. Eight samples of each group were taken from the top $30 \mathrm{~cm}$ of the stems, and 8 from the bottom $30 \mathrm{~cm}$. Although both top and bottom samples were taken from two or three stems, the criterion of independence of samples was believed to be upheld; stems were selected without regard to location within the 2 $\mathrm{m}^{2}$ area. The experimental design was therefore initially that of a two-way analysis of variance (ANOVA) with two levels of both age and depth, and eight replicates per cell.

Samples were obtained by carefully clipping off the 
TABLE 2. Effects of diatom density and depth upon densities of plant-associated species using a one-way analysis of covariance with diatom density as the covariate and depth as the stratifying variable (Experiment 1). Ns = not significant; $*$ = significant at $\alpha=.05 ;^{* *}=$ significant at $\alpha=.01$. All organism densities are expressed as numbers per square centimetre: mean (SE).

\begin{tabular}{|c|c|c|c|c|c|c|}
\hline & $\begin{array}{l}\text { Young } \\
\text { plant top }\end{array}$ & $\begin{array}{c}\text { Young } \\
\text { plant bottom }\end{array}$ & $\begin{array}{l}\text { Old } \\
\text { plant top }\end{array}$ & $\begin{array}{l}\text { Old } \\
\text { plant bottom }\end{array}$ & $\begin{array}{l}\text { Diatom } \\
\text { density }\end{array}$ & Depth \\
\hline $\begin{array}{l}\text { Number of samples } \\
\text { Stem surface area }\left(\mathrm{cm}^{2}\right)\end{array}$ & $\begin{array}{c}8 \\
24.3(2.3)\end{array}$ & $\begin{array}{c}8 \\
34.5(2.9)\end{array}$ & $\begin{array}{c}6 \\
25.6(2.0)\end{array}$ & $\begin{array}{c}8 \\
37.1(3.7)\end{array}$ & - & - \\
\hline Diatoms $\left(10^{3}\right)$ & $124.2(29.6)$ & $153.9(35.2)$ & $394.3(100)$. & $384.9(37.8)$ & - & - \\
\hline $\begin{array}{l}\text { Sida (immatures) } \\
\quad \text { (adults) } \\
\text { Simocephalus }\end{array}$ & $\begin{array}{l}.838(.143) \\
.015(.007) \\
.00(.000)\end{array}$ & $\begin{array}{l}.439(.102) \\
.022(.013) \\
.021(.009)\end{array}$ & $\begin{array}{l}.742(.205) \\
.052(.045) \\
.00(.000)\end{array}$ & $\begin{array}{l}.202(.069) \\
.049(.017) \\
.020(.009)\end{array}$ & $\begin{array}{l}\text { NS } \\
\text { NS } \\
\text { NS }\end{array}$ & $\begin{array}{c}* * \\
\text { NS } \\
*\end{array}$ \\
\hline $\begin{array}{l}\text { Alona } \\
\text { Acroperus } \\
\text { Total chydorids }\end{array}$ & $\begin{array}{l}.114(.049) \\
.037(.021) \\
.175(.079)\end{array}$ & $\begin{array}{l}.297(.077) \\
.010(.007) \\
.630(.122)\end{array}$ & $\begin{array}{l}1.46(.407) \\
.129(.047) \\
1.78(.405)\end{array}$ & $\begin{array}{l}.666(.066) \\
.078(.017) \\
1.58(.161)\end{array}$ & $\begin{array}{l}* * \\
\text { NS } \\
* *\end{array}$ & $\begin{array}{l}\text { NS } \\
\text { NS } \\
\text { NS }\end{array}$ \\
\hline Total chironomids & $.111(.043)$ & $.488(.087)$ & $.885(.122)$ & $1.92(.184)$ & $* *$ & $* *$ \\
\hline
\end{tabular}

region above the desired portion of the stem with a scissors, slipping a $30-\mathrm{cm}$ section of clear Plexiglas tubing (inside diameter $=4.5 \mathrm{~cm}$ ) over the stem and inserting a Number 10 rubber stopper into the upper end of the tube. The stem was cut once more at the lower end of the tube, and a second stopper was inserted to seal off the contents. When a stem was disturbed during this process, it was discarded and the process repeated on a different stem. The stem with its associated water was transferred to a 1-I bottle and preserved with Lugol's iodine solution. Periphyton was removed by repeated shaking of the samples, followed by scraping of the stem surface with ring washers of appropriate size. The diameters $(d)$ of the top and bottom of each stem section were measured with vernier calipers, and averaged. Stem length $(h)$ was measured as well, and surface area computed as $\pi d h$. The invertebrates present were counted using a modified Bogorov chamber (Gannon 1971). Subsamples were also collected on Millepore filters, which were then placed on microscope slides and cleared with clove oil. Total pennate diatom densities were estimated; live and dead cells were not distinguished.

\section{Results}

Two samples were removed from the analysis, one due to spillage, and the other because of biases introduced by the presence of a recently hatched cohort of 207 chironomid larvae. Stratum statistics for the remaining 30 samples are given in Table 2 .

Counts of the invertebrate species were first divided by the surface area of the stem. Justification for this is provided in Experiment 2 below. The plant samples differed substantially, even between replicates, in total pennate diatom density. Because the microcrustacean and chironomid community might be expected to be affected by periphyton concentration more than by plant age per se, diatom density was substituted for plant age in the analysis. The data analysis was therefore transformed from a simple two-way ANOVA to a one-way analysis of covariance, with depth as the stratifying variable and diatom density as the covariate. Densities of Alona, total chironomids, and juvenile Sida were first log-transformed to meet the assumptions of the covariance model. Transformations for other taxa were not necessary. Diatom density (cells per square centimetre) was independent of both surface area (simple linear regression) and depth (ANOVA).

The chironomids were more abundant on old stems, and highly correlated with diatom density (Fig. 2a). The correlation is no surprise, because most species included in the samples were case builders, and diatoms are an important constituent of the case material. Significantly higher densities of larvae were found near the base of both young and old stems (Fig. 2a).

The chydorids, also periphyton grazing species, were also positively correlated with diatom density (Fig. 2b). Depth did not significantly affect overall chydorid distribution. Statistics for individual species are summarized in Table 2.

Juvenile Sida were significantly more abundant near the surface; densities were also slightly higher on younger plants. Adults were evenly distributed with depth, and were slightly more abundant on older plants; numbers of adults were too low, however, to evaluate the meaning of these trends. Simocephalus serrulatus, a plant-associated filter feeder like Sida, also displayed no correlation with diatom density. Simocephalus was found only in the bottom samples, and most of the population probably resides close to the mud-water interface.

\section{Experiment 2: Effects of Plant Density and Surface Area \\ Methods}

A total of 276 birch dowels were driven into the sandy bottom at the western end of the lake on 18 May 1979 in the $3 \times 3 \mathrm{~m}$ grid shown in Fig. 3. Dowels were 


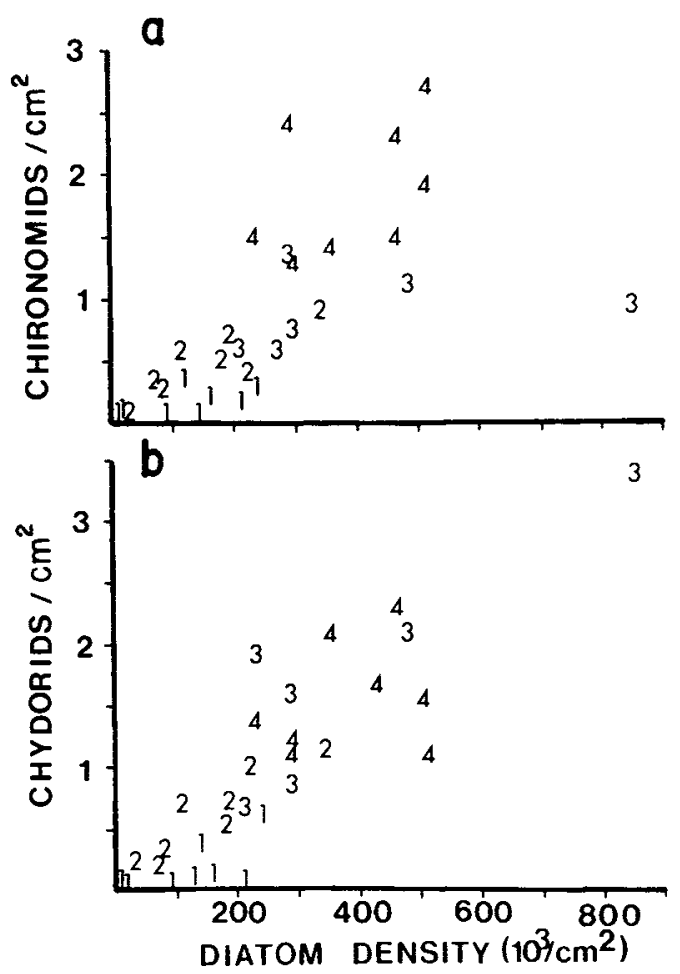

Fig. 2. Densities of (a) chironomid midge larvae, and (b) chydorid Cladocera on the surface of plant stems as a function of diatom density (Experiment 1 ). $1=$ young plants top; 2 = young plants-bottom; $3=$ old plants--top; $4=$ old plants-bottom.

of two sizes, $1.27 \mathrm{~cm}$ and $0.64 \mathrm{~cm}$ in diameter, and were arranged in two densities: "sparse" areas contained dowels spaced $30 \mathrm{~cm}$ apart, while "dense" areas contained four times as many dowels, placed 15 $\mathrm{cm}$ apart. Twenty-five $\mathrm{cm}$ of each dowel protruded above the substrate. Dowels to be sampled (shown with clear circles in Fig. 3) were fitted with rubber stoppers placed just above the substrate. They were situated as uniformly as possible within each of the sparse and dense areas. Dowels constituting the borders of these areas were not sampled. Forty dowels were sampled on 19 June 1979, 20 from sparse areas and 20 from dense areas. Ten dowels of each group were large, and 10 small.

Ropes attached to wooden posts at the four corners of the quadrat were used to maneuver the rowboat used in the study. The boat floated just above the dowels and could thus be positioned at any location within the quadrat. Sampling was accomplished by slipping a Plexiglas tube (inside diameter $=4.5 \mathrm{~cm}$ ) over each dowel, firmly sealing the stopper, and lifting the tube with enclosed dowel from the water. The tubes were shaken three times with filtered lake water to dislodge attached animals, which were collected in a 70- $\mu \mathrm{m}$ mesh Nitex sieve and transferred to $100-\mathrm{mL}$ jars. Organisms were narcotized with carbonated water (Club

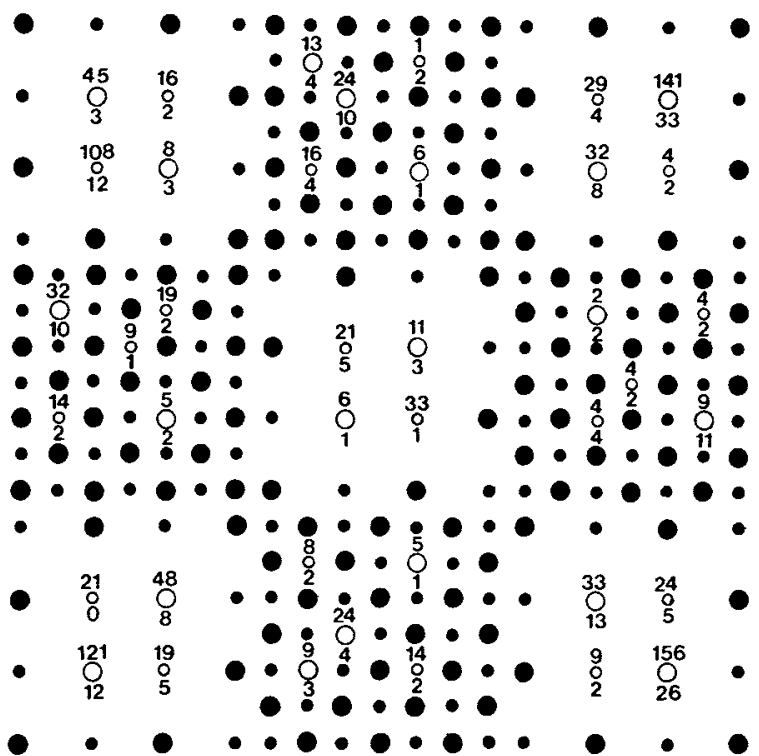

Fig. 3. Pattern of $1.27-\mathrm{cm}$ and $0.64-\mathrm{cm}$ dowels used in Experiment 2, and the number of Sida upon them. Numbers above the circles $=$ juveniles; numbers below the circles = adults. Two dowels (one large and one small) from the sparse areas in each of the four corners were again sampled in Experiment 3 .

Soda), then preserved in Formalin buffered with sodium tetraborate. Dowels were returned to their original locations following sampling, and some were again sampled in Experiment 3.

\section{Results}

The dowel rods were colonized principally by Sida, by chironomid larvae, and by two species of chydorid Cladocera, Alona costata, and Acroperus harpae. A number of cyclopoid copepod species were also present in the samples, especially Eucyclops speratus and Microcyclops varicans rubellus. Abundances of these taxa were analyzed using a two-way ANOVA with both surface area and density of the dowels considered as fixed effects of the model. Estimates of Alona, total chydorids, Eucyclops, Microcyclops, and both juvenile and adult Sida were first log-transformed in the analysis. Analyses for main effects of surface area and density are shown in Table 3. Interaction terms were not significant for any of the taxa.

Large $(1.27-\mathrm{cm})$ dowels were more heavily colonized than small $(0.64-\mathrm{cm})$ dowels by all taxa. Numbers of the cyclopoid copepods and total chironomids were approximately twice as great on large dowels, as expected from the doubled surface area available. The chydorid Cladocera were slightly more abundant on smaller dowels than predicted by available surface area (Table 3).

Plant position relative to neighboring plants was important to colonization by some taxa, but not all. The chydorids Acroperus and Alona were both approxi- 
TABLE 3. Effects of dowel density and surface area upon numbers per sample of plant-associated species (Experiment 2). Values represent means and (standard errors) for the 10 samples in each stratum. NS $=$ not significant; * $=$ significant at $\alpha=.05 ;{ }^{* *}=$ significant at $\alpha=.01$.

\begin{tabular}{|c|c|c|c|c|c|c|}
\hline \multirow[b]{2}{*}{ Taxon } & \multirow[b]{2}{*}{ Sparse-large } & \multirow[b]{2}{*}{ Dense-large } & \multirow[b]{2}{*}{ Sparse-small } & \multirow[b]{2}{*}{ Dense-small } & \multicolumn{2}{|c|}{ Main effect } \\
\hline & & & & & Density & $\begin{array}{c}\text { Surface } \\
\text { area }\end{array}$ \\
\hline $\begin{array}{l}\text { Sida (immatures) } \\
\text { Sida (ovigerous females) } \\
\text { Eggs per ovigerous female }\end{array}$ & $\begin{array}{l}60.0(18.1) \\
11.0(3.4) \\
3.95(.455)\end{array}$ & $\begin{array}{c}12.9(3.2) \\
4.8(1.2) \\
3.81(.471)\end{array}$ & $\begin{array}{c}28.4(9.2) \\
3.8(1.1) \\
3.62(.403)\end{array}$ & $\begin{array}{c}9.3(1.9) \\
2.3(0.3) \\
4.17(.508)\end{array}$ & $\begin{array}{c}* * \\
* \\
\text { NS }\end{array}$ & $\begin{array}{l}\text { NS } \\
* \\
\text { NS }\end{array}$ \\
\hline $\begin{array}{l}\text { Alona } \\
\text { Acroperus } \\
\text { Total chydorids }\end{array}$ & $\begin{array}{r}14.6(3.3) \\
1.8(0.4) \\
17.8(3.4)\end{array}$ & $\begin{array}{r}8.3(3.4) \\
0.9(0.5) \\
11.6(4.4)\end{array}$ & $\begin{array}{r}10.3(3.5) \\
0.4(0.2) \\
11.3(3.6)\end{array}$ & $\begin{array}{l}6.3(1.4) \\
0.3(0.2) \\
7.9(1.8)\end{array}$ & $\begin{array}{l}\text { NS } \\
\text { NS } \\
\text { NS }\end{array}$ & $\begin{array}{l}\text { NS } \\
* * \\
\text { NS }\end{array}$ \\
\hline $\begin{array}{l}\text { Eucyclops } \\
\text { Microcyclops } \\
\text { Total cyclopoids }\end{array}$ & $\begin{array}{l}4.4(0.8) \\
2.6(0.9) \\
9.5(1.2)\end{array}$ & $\begin{array}{r}4.2(0.9) \\
2.9(1.2) \\
10.4(2.0)\end{array}$ & $\begin{array}{l}1.6(0.6) \\
1.7(0.4) \\
5.0(1.2)\end{array}$ & $\begin{array}{l}1.6(0.5) \\
1.4(0.3) \\
4.9(0.7)\end{array}$ & $\begin{array}{l}\text { NS } \\
\text { NS } \\
\text { NS }\end{array}$ & $\begin{array}{l}* * \\
\text { NS } \\
* *\end{array}$ \\
\hline Chironomids & $94.8(9.8)$ & $94.3(12.5)$ & $48.7(5.6)$ & $49.8(7.2)$ & NS & $* *$ \\
\hline
\end{tabular}

mately twice as abundant on sparsely distributed dowels, although residual variability was high. In contrast, the distributions of the cyclopoid copepods and chironomids were not affected by dowel position.

Both juveniles and adults of Sida were found in significantly higher numbers on sparsely distributed dowels, and were most abundant at the four corners of the $3 \times 3 \mathrm{~m}$ grid (Fig. 3). The pattern was particularly pronounced for early instars, but was evident for ovigerous females as well, and was not attributable to differences in egg numbers of ovigerous females, which were relatively constant regardless of location (Table 3).

\section{EXPERIMENT 3: DiURNAL EFFECTS UPON THE Degree of Plant Utilization \\ Methods}

The number of individuals of Sida and other littoral species actually on substrates vs. swimming in the water column were compared during the day and at night. Dowel rods previously set up to study the effects of plant density and surface area (Experiment 2) were utilized as substrates. Two dowels, one large and one small, were sampled from each of the four corners of the grid, using a Plexiglas tube as in Experiment 2. Eight water samples were taken directly adjacent to the dowels with a $3.85-\mathrm{L}$ glass jar at the same time. Sampling was conducted on 5 August 1979 at midday and was repeated the following evening from 1130 to 0200 .

\section{Results}

Because "plant" samples taken during the day and at night ( $D P$ and $N P$ in Table 4 ) included $475 \mathrm{~mL}$ of water as well as the dowels themselves, the number of organisms assumed to have been swimming near the dowel but nonetheless included in the sample was calculated by multiplying the numbers in the corre- sponding water samples ( $D W$ and $N W$ ) by $0.1234(=$ $475 \mathrm{~mL} / 3.85 \mathrm{~L}$ ). This amount was subtracted from the plant samples to obtain the probable number of organisms actually attached to each dowel $\left(D P^{\prime}\right.$ and $\left.N P^{\prime}\right)$ at the time it was sampled. Thus,

$$
D P^{\prime}=D P-0.1234(D W) \text {, and }
$$

Var. of $D P^{\prime}=($ Var. of $D P)+(0.1234)^{2}($ Var. of $D W)$

$$
N P^{\prime}=N P-0.1234(N W) \text {, and }
$$

Var. of $N P^{\prime}=($ Var. of $N P)+(0.1234)^{2}($ Var. of $N W)$

Relative numbers of each taxon which were free swimming vs. attached were not compared statistically; an inspection of columns $D W$ vs. $D P^{\prime}$ and $N W$ vs. $N P^{\prime}$ shows that all species were either highly plantassociated or almost completely free-swimming. Numbers of each taxon both on the dowels and in the water were tested for day-night differences using the MannWhitney $U$ test (Table 4).

"Free-swimming" species (Bosmina longirostris, Ceriodaphnia lacustris, Diaptomus oregonensis, Mesocyclops edax, Epischura lacustris) appeared neither to utilize nor avoid the dowels: calculated values of $D P^{\prime}$ and $N P^{\prime}$ were close to zero. Bosmina were more abundant in the plant samples at night than expected, but this was probably due to depth stratification by the animals; water samples were taken slightly nearer the surface than were the corresponding plant samples in some instances. Densities of Ceriodaphnia in the water column increased slightly at night; densities of all three copepod species increased markedly.

In contrast, "plant-associated" species (Sida, the cyclopoid copepods Eucyclops and Microcyclops, all chydorids and the chironomids) were found only rarely away from plant surfaces. The degree of plant association differed diurnally for some species. Some of the Chydoridae, absent from the water samples during the day, were present in the water column in small 
TABLE 4. Diurnal effects upon the degree of association of littoral invertebrates with aquatic plants (Experiment 3). Values represent means and (standard errors) for the eight samples in each stratum. NS $=$ not significant; ${ }^{*}=$ significant at $\alpha$ $=.05 ; * *=$ significant at $\alpha=.01$ (Mann-Whitney $U$ test). Data are expressed as numbers per sample.

\begin{tabular}{|c|c|c|c|c|c|c|c|c|}
\hline \multirow[b]{2}{*}{ Taxon } & \multicolumn{3}{|c|}{ Day } & \multicolumn{3}{|c|}{ Night } & \multicolumn{2}{|c|}{$\begin{array}{l}\text { Day-night } \\
\text { differences }\end{array}$} \\
\hline & Water $(D W)$ & Plants $(D P)$ & $D P I$ & Water $(N W)$ & Plants $(N P I)$ & $N P$ & Water & Plants \\
\hline $\begin{array}{l}\text { Sida (immatures) } \\
\text { Sida (ovigerous females) }\end{array}$ & $\begin{array}{l}0.00(0.00) \\
0.00(0.00)\end{array}$ & $\begin{array}{l}21.5(4.73) \\
7.87(3.70)\end{array}$ & $\begin{array}{l}21.5(4.73) \\
7.87(3.70)\end{array}$ & $\begin{array}{l}0.50(0.27) \\
0.00(0.00)\end{array}$ & $\begin{array}{l}25.9(9.83) \\
11.7(2.85)\end{array}$ & $\begin{array}{l}25.8(9.83) \\
11.7(2.85)\end{array}$ & $\begin{array}{l}\text { NS } \\
\text { NS }\end{array}$ & $\begin{array}{l}\text { NS } \\
\text { NS }\end{array}$ \\
\hline $\begin{array}{l}\text { Bosmina } \\
\text { Ceriodaphnia } \\
\text { Diaptomus }\end{array}$ & $\begin{array}{l}52.8(0.16) \\
2.12(0.75) \\
0.25(0.16)\end{array}$ & $\begin{array}{l}9.75(2.52) \\
0.00(0.00) \\
0.12(0.12)\end{array}$ & $\begin{array}{r}3.23(2.56) \\
-0.26(9.09) \\
0.09(0.12)\end{array}$ & $\begin{array}{l}74.9(22.9) \\
11.5(1.53) \\
25.7(3.78)\end{array}$ & $\begin{array}{l}24.4(2.70) \\
1.62(0.53) \\
2.37(0.84)\end{array}$ & $\begin{array}{r}15.1(3.89) \\
0.21(0.56) \\
-0.80(0.96)\end{array}$ & $\begin{array}{l}\text { NS } \\
* * \\
* *\end{array}$ & $\frac{-}{-}$ \\
\hline $\begin{array}{l}\text { Epischura } \\
\text { Macrocyclops } \\
\text { Mesocyclops } \\
\text { Eucyclops } \\
\text { Microcyclops }\end{array}$ & $\begin{array}{l}0.00(0.00) \\
0.00(0.00) \\
0.00(0.00) \\
0.37(0.37) \\
0.00(0.00)\end{array}$ & $\begin{array}{l}0.00(0.00) \\
0.37(0.37) \\
0.12(0.12) \\
4.00(0.89) \\
4.00(1.25)\end{array}$ & $\begin{array}{l}0.00(0.00) \\
0.37(0.37) \\
0.12(0.12) \\
3.95(0.89) \\
4.00(1.25)\end{array}$ & $\begin{array}{l}1.87(0.69) \\
0.25(0.16) \\
5.50(1.08) \\
0.37(0.37) \\
8.12(1.69)\end{array}$ & $\begin{array}{l}0.12(0.12) \\
0.37(0.18) \\
1.87(0.87) \\
3.50(0.98) \\
5.87(0.95)\end{array}$ & $\begin{array}{r}-0.11(0.14) \\
0.34(0.18) \\
1.20(0.88) \\
3.45(0.99) \\
4.87(0.97)\end{array}$ & $\begin{array}{l}* * \\
\text { NS } \\
* * \\
\text { NS } \\
* *\end{array}$ & $\begin{array}{l}- \\
\text { NS } \\
\text { NS } \\
\text { NS } \\
\text { NS }\end{array}$ \\
\hline $\begin{array}{l}\text { Acroperus } \\
\text { Alona } \\
\text { Total chydorids }\end{array}$ & $\begin{array}{l}0.00(0.00) \\
0.00(0.00) \\
0.00(0.00)\end{array}$ & $\begin{array}{l}1.50(0.63) \\
18.5(3.49) \\
22.1(3.79)\end{array}$ & $\begin{array}{l}1.50(0.63) \\
18.5(3.49) \\
22.1(3.79)\end{array}$ & $\begin{array}{l}0.25(0.16) \\
0.00(0.00) \\
0.62(0.26)\end{array}$ & $\begin{array}{l}3.00(1.19) \\
30.6(4.36) \\
38.4(5.78)\end{array}$ & $\begin{array}{l}2.97(1.19) \\
30.6(4.36) \\
38.3(5.78)\end{array}$ & $\begin{array}{l}\text { NS } \\
\text { NS } \\
\text { NS }\end{array}$ & $\begin{array}{l}\text { NS } \\
* \\
\text { NS }\end{array}$ \\
\hline Total chironomids & $0.50(0.27)$ & $23.9(1.71)$ & $23.8(1.71)$ & $0.37(0.26)$ & $25.9(1.83)$ & $25.8(1.84)$ & NS & NS \\
\hline
\end{tabular}

numbers at night. Macrocyclops, found only in the plant samples during the day, apparently increased its swimming at night as well. The behavior of Sida did not change at night.

\section{Experiment 4: Patch Size and the Degree of Clumping among LitToral Cladocera}

\section{Methods}

A $10 \times 10 \mathrm{~m}$ quadrat was constructed in a stand of the white water lily Nymphaea odorata at the western end of the lake on 8 May 1977. The quadrat was subdivided into $254-\mathrm{m}^{2}$ sections with nylon twine, which was placed on the lake bottom. Series of samples were collected by boat from the quadrat on 23 May and 5 July 1977. Samples, consisting of one leaf of $\mathrm{Nym}$ phaea and $10 \mathrm{~L}$ of surrounding water, were collected with a "box sampler," constructed to sample floatingleaved vegetation (Fig. 4). The sampler was a plastic container fitted on one side with a sliding aluminum sheet which could be drawn over a second aluminum blade, snipping the Nymphaea stems at a depth of approximately $15 \mathrm{~cm}$. The pull cords which closed the aluminum door were strung along a $1.3-\mathrm{m}$ pole affixed to one side of the sampler, ensuring that the sample estimates of the Cladocera were not biased by the proximity of the boat used. A polyethylene funnel, $12.5 \mathrm{~cm}$ in diameter at its base and with windows of $70-\mu \mathrm{m}$ aperture Nitex screening, was attached to the side of the sampler opposite the blades. The sampler, with enclosed leaf, was inverted and then lifted from the water, funnel downward, concentrating the organisms in the $10 \mathrm{~L}$ volume of water to approximately 50 $\mathrm{mL}$ at the base of the funnel, where a short piece of rubber hose and a pinch clamp were attached. Samples were transferred to $100-\mathrm{mL}$ jars and preserved in buffered Formalin.

A portion of the quadrat extended beyond the $\mathrm{Nym}$ phaea stand into open water. Seven of the 63 samples taken on 23 May, and 6 of the 64 samples on 5 July, were collected $1 \mathrm{~m}$ from the margin of the vegetation and contained $10 \mathrm{~L}$ of water but no leaves of $\mathrm{Nym}$ phaea. The remainder of the samples each consisted of a single leaf of Nymphaea in addition to the $10 \mathrm{~L}$ of water. Leaves selected for sampling were $1 \mathrm{~m}$ or more away from each other to avoid disturbances created by the sampling procedure. Only leaves which were not touching their neighbors were chosen in order to minimize the capture of organisms from adjacent leaves. A maximum of four samples were collected from each 4- $\mathrm{m}^{2}$ section. High plant densities or disturbance of plants by either the sampler or the boat often reduced the number of samples taken in a particular section. Fewer than four samples were also taken from sections located partly or completely in open water. Planar coordinates locating the position of each sample in the quadrat were recorded. Both series of samples were taken over a $4-\mathrm{h}$ period at midday on calm, overcast days.

\section{Results}

Many techniques exist for quantifying distributional pattern for natural populations (Pielou 1974). Two concepts which are both measurable and qualitatively distinguishable are those of "patch size" (the dimensions of areas containing observably higher than average numbers of individuals) and the "degree of clumping," often measured by a variance-to-mean ratio or modification thereof. 


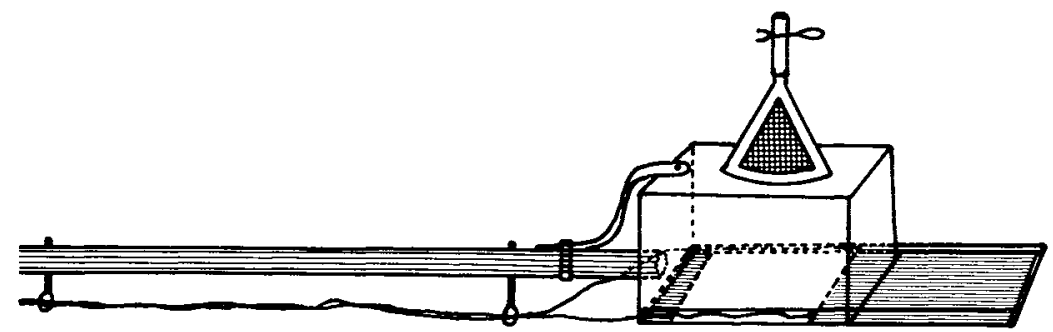

FIG. 4. "Box Sampler" designed to collect invertebrates associated with floating-leaved vegetation in Experiment 4.

Estimates of both patch size and degree of clumping were applied to the microdistribution of littoral species. Abundances per sample for six cladoceran species are presented here. The data from which patch sizes and degree of clumping were derived are shown visually in Fig. 5a-l. Sample locations are shown with dots. Isopleths were drawn by hand, using linear interpolation. The technique presented difficulties only in one corner of the quadrat, which contained no samples. This area was therefore not included in the maps. To avoid subjective biases in constructing the maps, the numerical difference between isopleths was set at one standard deviation $(s)$ of the overall population mean. Values for $s$ are included with each map. For example, all samples within the most coarsely hatched area in the map of Sida on 23 May contained between 0 and 59.7 individuals. The use of $s$ partitioned the total range of abundances with roughly the same number of isopleths for each species, and thus provided a reasonable means of comparing populations differing in abundance.

Patches on these maps were arbitrarily defined as contiguous areas containing only samples with $>2 s$ individuals. Degree of clumping, based upon numbers per sample for all samples in the $10 \times 10 \mathrm{~m}$ quadrat, was estimated by the coefficient of variation rather than by a variance-to-mean ratio, because the standard deviation had been shown in previous work to be a linear function of the mean estimate for a number of littoral species (G. W. Fairchild, personal observation).

Results are presented for three plant-associated species (Sida, Acroperus, Alona) and three free-swimming species (Bosmina, Ceriodaphnia, Scapholeberis kingi). Individuals of the plant-associated species were found only very infrequently in samples containing no leaves of Nymphaea, and these samples were not included in either the mapping or the analysis (Table 5). All samples were considered for the three free-swimming species.

Whereas small patches containing just one or two samples were observed for the free-swimming species, patches covering much larger areas and including many samples were also noted. Patches $12.4 \mathrm{~m}^{2}$ and $17.3 \mathrm{~m}^{2}$ in size were observed for Ceriodaphnia on 23 May and 5 July, respectively. Bosmina formed a patch of $12.5 \mathrm{~m}^{2}$ on $5 \mathrm{July}$. Subsequent work has shown (Fairchild 1980) that Bosmina has consistently higher densities in the open water in Cochran Lake, and avoidance of the stand of Nymphaea may have produced its distribution pattern. Patches were smaller for Scapholeberis than for the other two free-swimming species.

Population densities of Sida were highest near the margin of the vegetation. On 23 May, when the leaves of Nymphaea were more sparsely distributed (8.3 leaves $/ \mathrm{m}^{2}$ ), this zone of particularly high densities of Sida extended over a distance of approximately $2 \mathrm{~m}$ from the margin of the vegetation. On 5 July, when plant densities had increased $\left(26.1\right.$ leaves $\left./ \mathrm{m}^{2}\right)$, the apparent edge effect was limited to two plants in small peninsulas of vegetation extending into the open water (Fig. 5b). Densities were very high on these plants (179 and 220 individuals) as compared to the mean density of 17.0 individuals per plant in the quadrat as a whole.

Although distributions are mapped in the same way for plant-associated species as for free-swimming species, the interpretation of results differs. Most individuals of Acroperus, Alona, and Sida are actually in contact with plant surfaces (Table 4). Distributions are thus discontinuous, and patch sizes denote the degree to which plants in a given area all have high numbers of organisms. Areal dimensions of patches are accordingly not calculated for plant-associated species in Table 5. Clearly, whereas Sida is consistently distributed on plants near the margin of the vegetation, patches larger than single plants are not distinguishable for either Acroperus or Alona. The high coeffcient of variation for these species (Table 5) is probably caused by plant-to-plant differences such as diatom density (Table 2) and plant surface area (Table 3).

\section{Discussion}

Free-swimming species of the littoral (Bosmina, Ceriodaphnia, Scapholeberis) are often found beyond the margin of the vegetation (Pennak 1966). Dispersion patterns of these species showed high concentrations of individuals extending over several or more square metres of lake surface. Swarming behavior by littoral Cladocera (Brandl and Fernando 1971, Ratzlaff 1974) 

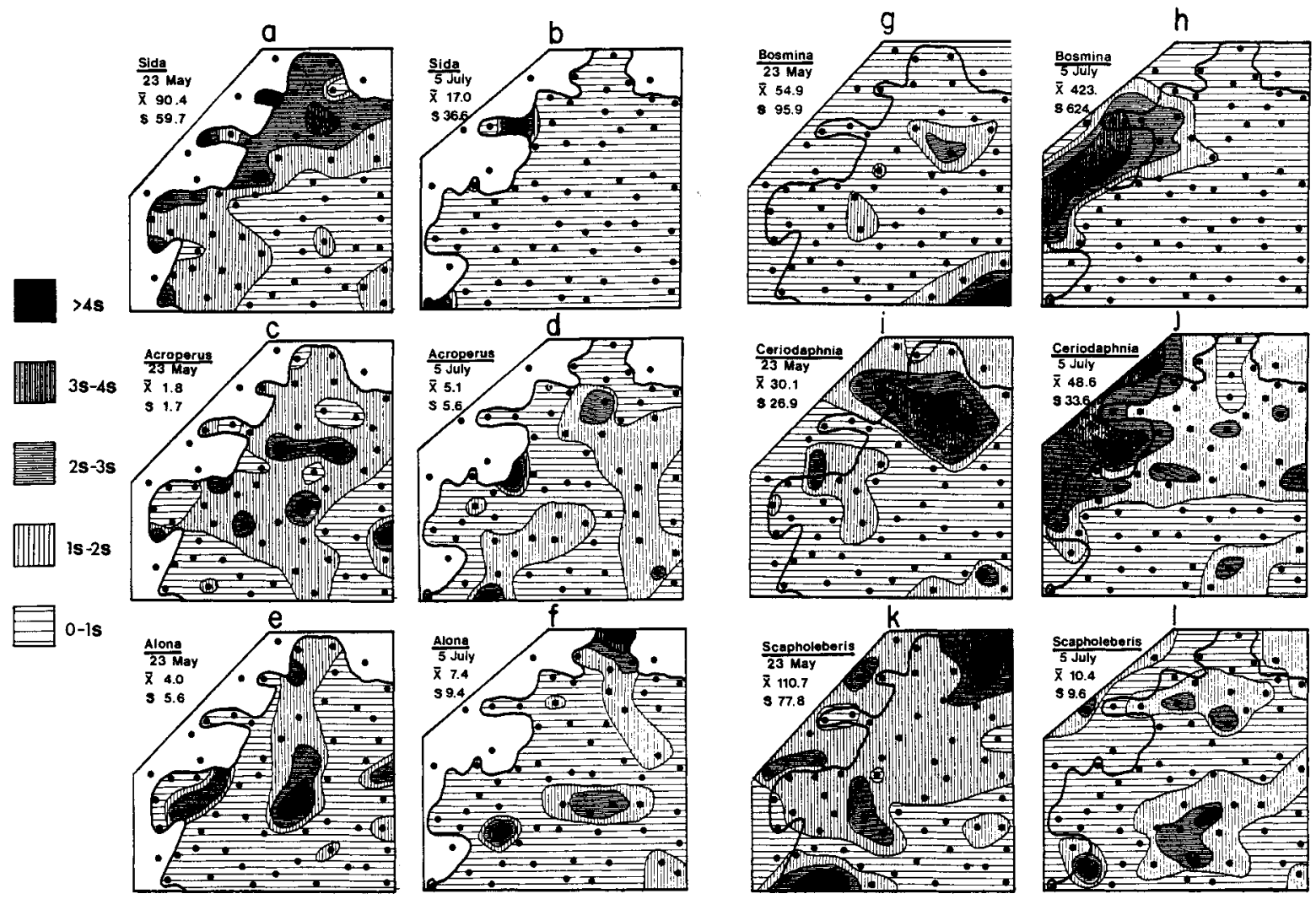

Fig. 5. Distribution based upon numbers per sample of six species of Cladocera, representing 64 samples on 23 May, and 63 samples on 5 July 1977. Locations of samples are shown by dots. Only samples with plants were considered for Sida, Acroperus, and Alona. Samples taken in the open water were also considered for Bosmina, Ceriodaphnia, and Scapholeberis. The numerical difference between isopleths $(s)$ is shown with each map. The boundary of the Nymphaea stand is shown with heavy lines. The triangle removed from the upper left of each map contained no samples.

typically results in much smaller aggregations, usually contained in $<1 \mathrm{~L}$ of total water volume. The dispersion patterns seen in Experiment 4 are better interpreted as the result of water movements within the littoral or of swimming responses to the distribution of aquatic macrophytes. Similar patches, up to $10 \mathrm{~m}$ in diameter, were found by Gliwicz and Rybak (1978) for Bosmina longirostris in Mikolajskie Lake, Poland, and did not persist in one place from day to day. The large copepods Epischura lacustris, Diaptomus oregonensis, and Mesocyclops edax become abundant in the surface waters of Cochran Lake at night. Similar patterns of upward migration at night by free-swimming copepods have been well documented by numerous authors.

The distribution of plant-associated species is strongly influenced by a number of primarily physical factors like plant surface area, plant position, and depth. Periphyton density also affects some species, and other biological features of the littoral environment not specifically examined in this paper may be important as well. Abundances of both the chironomid larvae and microcrustacea varied directly with the amount of surface area available to them (Table 3). It is probably appropriate to express densities of these taxa as numbers per unit plant surface for plants of simple morphology, although a number of alternative expressions of density are in current use, as reviewed by Soszka (1975).

The distribution patterns of the chydorids (Acroperus, Alona) seem to be the results of plant-to-plant variation; larger patches were not evident. That small patches of chydorids do occur on the mud substrate has been demonstrated by Whiteside et al. (1978).

The cyclopoid copepods Microcyclops, Eucyclops, and Macrocyclops albidus, like the chydorids, showed a high affinity for plant surfaces (Table 4), and much of their food may consist of species found on aquatic plants (Fryer 1957). The means by which these copepods locate plants has yet to be examined.

Although the numbers of chironomids, Sida, Macrocyclops, and Eucyclops did not vary diurnally, the chydorid Cladocera were approximately twice as abundant at night. Nocturnal migrations upward from the lake sediments have been noted previously (Szlauer 1963, Whiteside 1974). What must be stressed 
TABLE 5. Measures of mean patch size in square metres, mean number of samples per patch, and the degree of clumping expressed as the coefficient of variation for three plant-associated (Sida, Acroperus, and Alona) and three free-swimming (Bosmina, Ceriodaphnia, and Scapholeberis) species (Experiment 4). Calculations are based on numbers of organisms per sample.

\begin{tabular}{|c|c|c|c|c|}
\hline \multirow[b]{2}{*}{ Taxon } & \multicolumn{2}{|c|}{$\begin{array}{l}\text { Patch size }\left(\mathrm{m}^{2}\right) \text { and } \\
\text { (no. samples per patch) }\end{array}$} & \multicolumn{2}{|c|}{$\begin{array}{l}\text { Coefficient } \\
\text { of variation } \\
(s / \bar{x}) 100\end{array}$} \\
\hline & 23 May & 5 July & 23 May & 5 July \\
\hline Sida (Total) & $-(3.0)$ & $-(1.0)$ & 68 & 215 \\
\hline $\begin{array}{l}\text { Acroperus } \\
\text { Alona }\end{array}$ & $\begin{array}{l}-(1.2) \\
-(2.0)\end{array}$ & $\begin{array}{l}-(1.0) \\
-(1.7)\end{array}$ & $\begin{array}{r}92 \\
130\end{array}$ & $\begin{array}{l}110 \\
128\end{array}$ \\
\hline $\begin{array}{l}\text { Bosmina } \\
\text { Ceriodaphnia } \\
\text { Scapholeberis }\end{array}$ & $\begin{array}{l}1.4(1.5) \\
4.5(4.0) \\
2.5(2.2)\end{array}$ & $\begin{array}{r}12.5(8.0) \\
3.3(2.5) \\
1.1(1.4)\end{array}$ & $\begin{array}{r}174 \\
89 \\
71\end{array}$ & $\begin{array}{r}148 \\
69 \\
93\end{array}$ \\
\hline
\end{tabular}

for both the free-swimming and plant-associated groups, however, is that whatever biotic interactions occur on the plants and in the water column (e.g., competition for food or available plant surface, or predation) must occur with greater frequency or intensity at night, when organisms are most densely concentrated. Total densities of all plant-associated taxa increased by one-third at night, while densities of freeswimming species more than doubled.

The niche of Sida crystallina in the littoral zone appears to be unique. The species is largely confined to the littoral zone by its attachment to aquatic macrophytes, but unlike most plant-associated species is a phytoplankton filter feeder. Its microdistribution was not significantly affected by periphyton density (Table 4) in this study, although Young (1945) has suggested that Sida may be inhibited by large amounts of periphyton. Early instar individuals were distributed nearer the surface than were adults (Table 4), and swam between plants more frequently (Table 1). Swimming individuals locate new plants visually. Many of these observations confirm and quantify previous suggestions by Szlauer (1973).

The frequency of movement between plants and the swimming behavior of the animals probably explain the high densities of Sida on plants near the margin of a stand of vegetation as reported in Experiments 2 and 4 . The reasoning is best understood by first considering idealized organisms. One is an infrequent and poor swimmer. When disturbed, it immediately reattaches to the nearest available substrate, either the original plant or the first plant encountered in any given direction. The other swims frequently and well, often choosing to remain in the water column for longer periods of time and covering greater distances. Reattachment, when it does occur, is accomplished by locating the plant nearest the individual at the moment.

For the first organism one would predict approxi- mately constant numbers per plant, regardless of plant density. The infrequent individuals which travel between adjacent plants do so directly. Each plant is therefore just as likely to lose an individual through emigration to another plant as it is to receive an immigrant from that plant. The magnitudes of the exchange rates are presumably proportional to the number of organisms resident on each plant, so that these abundances will tend to be uniform at steady state.

For the other organism, however, approximately constant numbers per unit lake surface area are predicted. Movements do not occur merely from plant to plant, but involve a substantial period of swimming. Frequencies of immigration depend upon whether or not a plant is closest to the position of the organism when it decides to reattach. Thus isolated plants surrounded by larger volumes of open water should receive more immigrants, while the probability of an individual emigrating is presumably equal among all plants. In effect, were one to multiply the average number of organisms per plant times the number of plants per square metre, the resulting estimate expressed as organisms per square metre would be approximately the same regardless of plant density. The reasoning used in this second case should apply to organisms swimming from any plant within a stand of vegetation, and to those traveling over longer distances from other stands of vegetation as well.

The behavior of most littoral species should lie somewhere between these theoretical extremes. Sida has been shown to swim frequently between plants. Young (1945), who cleaned the surfaces of Scirpus stems in Douglas Lake and observed recolonization rates of plant-associated organisms, found Sida in abundance after $3 \mathrm{~d}$, when densities of periphyton and other invertebrates were still very low. Juveniles swim more frequently than adults, and appear to swim for longer periods of time before reattaching. Juveniles should thus more closely approach the second type of extreme described than should the adults.

The distributions of adults and juveniles (Fig. 3) in fact support these predictions. Juveniles are proportionately in higher abundance than adults on isolated plants, particularly in the four corners of the $3 \times 3 \mathrm{~m}$ grid, although adults cluster to some degree on isolated plants as well.

The increased densities of Sida on plants near the edge of a stand of vegetation are accentuated as the size and density of the plants increase during the summer (Fig. 5a, b). Effectively, the amount of open water surrounding edge plants remains high, while distances between plants in the interior of the stand steadily decrease.

The effects of plant density were variable for the other taxa examined; the chydorids generally increased in numbers on isolated plants, while the chironomids showed no effect of plant position. Differing behaviors of these species, and the degree to which 
they utilize the lake bottom in addition to plant surfaces, may be expected to influence the results.

The capacity of Sida to attach to aquatic vascular plants is an adaptation shared by Simocephalus and a number of littoral cyclopoid copepods. To an organism which uses aquatic plants simply as a physical support, there may be several benefits of attachment:

1. Attachment may reduce susceptibility to visual predation. Laboratory observations demonstrate that swimming individuals of Sida are eaten much more quickly by fish fry than are attached individuals (G. W. Fairchild, personal observation). Other work has shown, however, that fish fry (Phoenix 1976) as well as salamanders (Henderson 1973) search plants for attached food items and may constitute the principal form of mortality for Sida as well as other plant-associated species. Largemouth bass fry feed extensively upon populations of Sida during June and July in Cochran Lake (Fairchild 1980).

2. Nonmotility may result in decreased contact with sit-and-wait invertebrate predators. Johnson and Crowley's (1980) conclusion that the less motile Simocephalus suffered less predation by damselflies than did the free-swimming species Daphnia pulex provides an excellent example of the virtue of a sedentary habit in some situations. Sida was a major component in the diet of the damselfly $E n$ allagma boreale in Pearlstone's (1971) study in Marion Lake, British Columbia, so nonmotility certainly is not an adequate defense against invertebrate predators generally.

3. Support by aquatic plants must constitute a considerable energy saving for an organism which must otherwise swim continuously as it feeds. Further study of the respiration of organisms like Sida which are capable of both sitting and swimming may provide an estimation of just how important swimming is to the energy budgets of zooplankton species. Certainly the observation that Sida remains attached to aquatic plants at night when visual predation is minimal provides support to the idea that the energy saved may be significant.

Two potential costs of attachment can also be expected:

1. An attached organism is exposed to plant-associated predators, including a diversity of oligochaete, flatworm, and chironomid species. Total population size in a lake may also be limited by available sites for attachment.

2. Primary productivity of the phytoplankton is frequently reduced in the littoral zone of some lakes (e.g., Kowalczewski and Pieczynska 1976, Komarkova and Marvan 1978), presumably through competition for light and nutrients with aquatic macrophytes. Thus, the frequency of movement and the search behavior for new plants displayed by
Sida may, by maximizing the probability of reaching isolated plants, often those on the littoral margin, also increase its access to phytoplankton in some lakes.

\section{ACKNOWLEDGMENTS}

I thank J. Lehman, J. E. Gannon, and G. Fowler for their guidance of the research, and E. Stoermer and S. Mozley for help with the preparation and identification of diatoms and chironomids. The University of Michigan Biological Station generously provided field equipment and laboratory facilities. I was assisted in portions of the fieldwork by J. Mechling, P. Fairchild, and M. Bautista. Criticisms of the manuscript by J. Korstad, A. Kluge, and B. Dorazio are also greatly appreciated.

\section{Literature Cited}

Brandl, Z., and C. H. Fernando. 1971. Microaggregation of the cladoceran Ceriodaphnia affinis Lilljeborg with a possible reason for microaggregation of zooplankton. Canadian Journal of Zoology 49:775.

Daggett, R. F., and C. C. Davis. 1974. A seasonal quantitative study of the littoral Cladocera and Copepoda in a bog pond and an acid marsh in Newfoundland. Internationale Revue der Gesamten Hydrobiologie 59:667-683.

Fairchild, G. W. 1980. Effects of littoral conditions on the distribution, behavior, and population dynamics of a filter feeding microcrustacean: Sida crystallina. Dissertation. University of Michigan, Ann Arbor, Michigan, USA.

Fryer, G. 1957. The food of some freshwater cyclopoid copepods and its ecological significance. Journal of Animal Ecology 26:263-286.

Gerking, S. D. 1957. A method of sampling the littoral macrofauna and its application. Ecology 38:219-226.

Gillespie, D. M., and C. J. D. Brown. 1966. A quantitative sampler for macroinvertebrates associated with aquatic macrophytes. Limnology and Oceanography 11:404-406.

Gliwicz, Z. M., and J. I. Rybak. 1976. Zooplankton. Chapter 5 in E. Pieczynska, editor. Selected problems of lake littoral ecology. University of Warsaw, Warsaw, Poland.

Goulden, C. E. 1971. Environmental control of the abundance and distribution of the Chydorid Cladocera. Limnology and Oceanography 16:320-331.

Henderson, E. A. 1973. The specialized feeding behavior of Ambystoma gracile in Marion Lake, British Columbia. Canadian Field Naturalist 87:151-154.

Johnson, D. M. 1973. Predation by damselfly naiads on Cladoceran populations: fluctuating intensity. Ecology 54:251268.

Johnson, D. M., and P. H. Crowley. 1980. Odonate "Hide and Seek": habitat-specific rules? Pages 569-579 in W. C. Kerfoot, editor. American Society of Limnology and Oceanography Special Symposium 3: The evolution and ecology of zooplankton populations. New England University Press, Hanover, New Hampshire, USA.

Keen, R. 1973. A probabilistic approach to the dynamics of natural populations of the Chydoridae (Cladocera, Crustacea). Ecology 54:524-534.

Komarkova, J., and P. Marvan. 1978. Primary production and functioning of algae in the fishpond littoral. Pages 321331 in D. Dykyjova and J. Kvet, editors. Pond littoral ecosystems. Springer-Verlag, New York, New York, USA.

Kowalczewski, A., and E. Pieczynska. 1976. Algae. Chapter 4 in E. Pieczynska, editor. Selected problems of lake littoral ecology. University of Warsaw, Warsaw, Poland.

Minto, M. L. 1977. A sampling device for the invertebrate fauna of aquatic vegetation. Freshwater Biology 7:425430. 
Pearlstone, P. 1971. Observations on a natural population of damselfly larvae. Thesis. University of British Columbia, Vancouver, British Columbia, Canada.

Pennak, R. W. 1962. Quantitative zooplankton sampling in littoral vegetation areas. Limnology and Oceanography 7:487-489.

. 1966. Structure of zooplankton populations in the littoral macrophyte zone of some Colorado lakes. Transactions of the American Microscopical Society 85:329-349.

Phoenix, D. 1976. Temporal dynamics of a natural multipredator-multiprey system. Dissertation. University of Pennsylvania, Philadelphia, Pennsylvania, USA.

Pielou, E. C. 1974. Population and community ecology. Gordon and Breach Science Publishers, New York, New York, USA.

Quade, H. 1969. Cladoceran faunas associated with aquatic macrophytes in some lakes in Northwestern Minnesota. Ecology 50:170-179.

Ratzlaff, W. 1974. Swarming in Moina affinis. Limnology and Oceanography 19:993-995.

Rosine, W. N. 1955. The distribution of invertebrates on submerged aquatic plant surfaces in Muskee Lake, Colorado. Ecology 36:308-314.

Smyly, W. J. P. 1958. The Cladocera and Copepoda (Crustacea) of the tarns of the English Lake District. Journal of Animal Ecology 27:87-103.
Soszka, G. J. 1975. The invertebrates on submerged macrophytes in three Masurian lakes. Ekologia Polska 23:371391.

Szlauer, L. 1963. Diurnal migrations of minute invertebrates inhabiting the zone of submerged hydrophytes in a lake. Schweizerische Zeitschrift für Hydrologie 25:56-64.

1973. Settlement of Sida crystallina O.F.M. on solid objects. Ekologia Polska 21:1-8.

Thomas, M. Pugh. 1963. Notes on the presence of Sida crystallina in the plankton and the origin of the freshwater plankton. Archiv für Hydrobiologie 59:103-109.

Whiteside, M. C. 1974. Chydorid (Cladocera) ecology: seasonal patterns and abundance of populations in Elk Lake, Minnesota. Ecology 55:538-550.

Whiteside, M. C., and J. B. Williams. 1975. A new sampling technique for aquatic ecologists. Internationale Vereinigung für Theoretische und Angewandte Limnologie, Verhandlungen 19: 1534-1539.

Whiteside, M. C., J. B. Williams, and C. P. White. 1978. Seasonal abundance and pattern of chydorid Cladocera in mud and vegetative habitats. Ecology 59:1177-1188.

Young, O. W. 1945. A limnological investigation of periphyton in Douglas Lake, Michigan. Transactions of the American Microscopical Society 64:1-20.

\section{ERRATUM}

In the paper by J. Ewel, C. Berish, B. Brown, N. Price, and J. Raich ("Slash and burn impacts on a Costa Rican wet forest site." Ecology 62:816-829. 1981), the values shown for sulfur in Figs. 4 and 6 were based on determinations of available soil sulfur. The values listed here were based on determinations of total soil sulfur, and are thus comparable to total values published in Figs. 4 and 6 for carbon and nitrogen.

In Fig. 4, correct values for total sulfur are: TO $3 \mathrm{~cm}$ IN SOIL $\left(27 \mathrm{~g} / \mathrm{m}^{2}\right)$, REMAINING (26\%), WOOD HARVEST (18\%), POST-BURN WIND \& LEACHING (7\%), and BURNED (49\%); ABOVEGROUND $\left(14 \mathrm{~g} / \mathrm{m}^{2}\right)$, REMAINING (13\%), WOOD HARVEST (34\%), BURNED (47\%), and POST-BURN WIND \& LEACHING $(6 \%)$.

In Fig. 6, correct values for total sulfur $\left(\mathrm{g} / \mathrm{m}^{2}\right)$ are: FOREST (27), DECOMPOSITION $(<1)$, WOOD HARVEST (5), SLASH (23), BURN (13), POSTBURN (10), and WIND \& LEACHED (1st RAIN) (2). 